\title{
Widespread presence of cytomegalovirus DNA in tissues of healthy trauma victims
}

\author{
R M G Hendrix, M Wagenaar, R L Slobbe, C A Bruggeman
}

\begin{abstract}
Aims-To determine the localisation of human cytomegalovirus (CMV) DNA in abdominal aorta, spleen, and transplantable organs, such as kidney, pancreas, and liver, obtained from healthy individuals; to characterise the cell type(s) in these tissues that serve as a reservoir for latent CMV.

Methods-CMV DNA was detected by dot blot DNA hybridisation and in situ DNA hybridisation with a probe for CMV major immediate early sequences (UL123) and nested PCR with primers derived from the CMV major immediate early (IE) gene exon 4 (UL123ex4). Samples of liver, abdominal aorta, spleen, kidney, and pancreas were obtained at necropsy or from donor kidneys from healthy subjects.

Results-CMV DNA was detected in most tissue samples using dot blot hybridisation and nested PCR. In situ hybridisation demonstrated that, in addition to smooth muscle cells in the arterial wall, hepatocytes, tubular and glomerular kidney cells, splenic red pulp cells, and pancreatic acinar cells also harboured CMV DNA. CMV DNA was detected in seropositive and in some seronegative subjects. Conclusion-CMV DNA is widely distributed in organs of healthy subjects. CMV DNA was found in various cell types in several organs, suggesting that during latency, CMV DNA is present thoughout the body.

( Clin Pathol 1997;50:59-63)
\end{abstract}

Keywords: cytomegalovirus; DNA; latency.

Infection by human cytomegalovirus (CMV), a herpesvirus, can result in a variety of disorders ranging from subclinical disease in normal subjects to fatal disease in immunocompromised patients. ${ }^{1}$ CMV can establish latent infections. Virus reactivation followed by active infection has been clearly demonstrated in recipients of organ transplants and often leads to life-threatening disease. ${ }^{\prime}$ Seronegative recipients of donor organs are at particular risk of developing CMV disease.' Molecular epidemiological studies have shown that two recipients receiving organs from the same donor excrete identical CMV strains in the urine, ${ }^{2}$ demonstrating that CMV transmission occurs with the graft. However, the cell types or the types of graft that serve as a reservoir for latent CMV are unkonwn. Several reports have suggested that latent $\mathrm{CMV}$ is present in the smooth muscle cells of the arterial wall..$^{3-6}$ Using PCR, we detected CMV DNA in the arterial wall in almost $70 \%$ of CMV seropositive patients ${ }^{5}$ and using in situ DNA hybridisation showed that arterial smooth muscle cells harboured the virus. In other reports CMV nucleic acids were found in peripheral leucocytes obtained from healthy CMV seropositive and seronegative subjects. ${ }^{78}$

In this report we describe the presence and location of CMV DNA in aorta, kidney, spleen, and pancreas of healthy organ donors.

\section{Methods}

Two groups of patients were included in this study. Group 1 comprised trauma victims (eight men, five women) available for donor nephrectomy. Samples were taken from the abdominal aorta, spleen and pancreas using strict aseptic surgical techniques. Twelve artery, 12 spleen and eight pancreatic samples were collected from these subjects. The mean age of the subjects was 35 years (range eight to 45 years). CMV DNA was detected using in situ DNA hybridisation and PCR. If there was sufficient tissue, dot blot DNA hybridisation was also done.

Group 2 comprised patients (six men, two women) with no relevant medical history who died of sudden cardiac arrest. Samples were taken at necropsy from the spleen, liver and kidney. All samples were taken within 12 hours of death using aseptic techniques. Eight spleen, eight liver, and eight kidney samples were collected. The mean age of the subjects was 65 years (range 54-75 years). In most cases CMV was detected by PCR only. Some liver and kidney samples were examined using in situ DNA hybridisation to identify the cell types harbouring CMV DNA.

All tissue samples were handled separately to avoid cross contamination. Tissues from which DNA was to be isolated were stored at $4^{\circ} \mathrm{C}$ in $50 \%$ ethanol. Tissues for in situ DNA hybridisation were fixed routinely in formalin and embedded in paraffin wax.

\section{SEROLOGY}

Seropositivity for CMV was determined for all patients using a latex agglutination test (CMVscan, Becton Dickinson, Cockeysville, MD, USA), an IgG ELISA from Organon Teknika, Boxtel, The Netherlands, and an in-house ELISA based on an AD169 infected cell lysate. $^{9}$ To establish active infection, IgM anti-CMV antibodies were detected using a capture ELISA technique as described by van 
Loon et al. ${ }^{10}$ All serum samples were taken directly on arrival of the subjects at our hospital.

\section{EXTRACTION OF DNA FROM TISSUE AND TISSUE} SECTIONS

DNA for dot blot hybridisation and PCR analysis was extracted from the ethanol preserved tissues. Small tissue samples were collected in $1.5 \mathrm{ml}$ polypropylene microcentrifuge tubes. Subsequent proteolytic digestion of all samples was carried out overnight at $50^{\circ} \mathrm{C}$

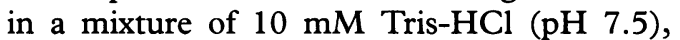
$5 \mathrm{mM}$ EDTA, $100 \mathrm{mM} \mathrm{NaCl}, 250 \mu \mathrm{g} / \mathrm{ml}$ proteinase $\mathrm{K}$ (Boehringer Mannheim, Mannheim, Germany), and $10 \mathrm{mg} / \mathrm{ml}$ SDS under constant agitation. The DNA was purified by phenol/ chloroform extraction and ethanol precipitation, and finally dissolved in $50 \mu \mathrm{l}$ distilled water. To exclude the possibility of cross contamination during these procedures, herring sperm DNA was included as a negative control.

\section{OLIGONUCLEOTIDES}

Oligonucleotides purchased from Eurogentec (Liege, Belgium) were derived from the CMV major immediate early gene exon 4 (UL123ex4). The nucleotide sequences of primers used for nested PCR are: first round: A1 5'-ACGAATTCGTAATGAAGCGCCGC ATTGA-3' and A2 5'-ACGAGCTGCAAT AGTGACGTGGGATCCA-3'; second round: B1 5'-ACGATTTCTCTGCATGAAGGTCT TTGC-3' and B2 5'-ACGAGCTCGTGGG ATCCATAACAGTAA-3'; internal probe: C 5'-CAGTAATTGTGGCGTAGAACAGTGA TCAGG-3'. The nested PCR product was 468 base pairs. The primer set specific for the $\beta$-globin gene has been described previously. ${ }^{11}$

HYBRIDISATION PROBES

A 7.0 kilobase EcoR1-Sall fragment from the EcoR1-J fragment of the CMV AD- $169^{5}$ strain, which contains the major immediate early gene, was used as a probe. The probe was labelled with biotin by incorporating biotin-11dUTP (Bethesda Research Laboratories, Maryland, USA) using a random primed DNA labelling kit (Boehringer Mannheim).

\section{DOT BLOT DNA HYBRIDISATION}

Transfer of cellular DNA to nitrocellulose, hybridisation conditions, and visualisation of successful hybridisation were carried out as described previously. ${ }^{5}$ The specificity of the biotinylated probe has been evaluated extensively. ${ }^{5}$

\section{NESTED PCR}

The reaction mixture contained standard PCR buffer (10× PCR buffer; Promega, USA) supplemented with $\mathrm{MgCl}_{2}$ to a final concentration of $2.4 \mathrm{mM}$ and $250 \mu \mathrm{M}$ of each dNTP in a reaction volume of $50 \mu \mathrm{l}$. One nanogram of each primer, 1 unit DNA polymerase (Amplitaq; Perkin Elmer Cetus, USA) and $200 \mathrm{ng}$ target DNA were added. After 30 cycles of one minute at $94^{\circ} \mathrm{C}$, one minute at $58^{\circ} \mathrm{C}$ and two minutes at $72^{\circ} \mathrm{C}$ on a Prem III thermal cycler (LEP Scientific, UK), $1 \mu$ l of the reaction mixture was transferred to the second reaction tube containing the nested primer for the second round PCR, carried out under the same conditions. After 40 cycles, $10 \mu \mathrm{l}$ of the second reaction mixture was subjected to electrophoresis on $2 \%$ agarose gels (Seakem GTG FMC Bioproducts, USA) and transferred to a nylon filter (Hybond N+ Amersham, Little Chalfont, UK). The internal oligonucleotide was end-labelled with ${ }^{32} \mathrm{P}$ and used as a probe for hybridisation to the nylon filters. All samples showing hybridisation were considered to contain CMV DNA.

PREVENTION OF FALSE POSITIVE PCR RESULTS Samples and buffers were prepared in different laboratories to prevent carry over of reaction products. A panel of related DNA viruses, including herpes simplex I, herpes simplex II, Epstein-Barr virus, varicella zoster virus, human herpes virus 6, rat CMV, and a panel of negative controls, including herring sperm DNA and DNA obtained from various organs of SPF Brown norway rats, was subjected to PCR with the CMV primer set.

IN SITU DNA HYBRIDISATION

The presence of CMV nucleic acids was detected using in situ DNA hybridisation on sections $4 \mu \mathrm{m}$ thick as described previously. ${ }^{5}$

IMMUNOHISTOCHEMISTRY

CMV specific antigens were detected immunohistochemically as described previously. ${ }^{12}$ A monoclonal antibody directed against the CMV 72 kilodalton IE antigen (UL123) (Dupont Speciality Diagnostics, Wilmington, USA) and the MC 222 monoclonal antibody, directed against the 65 kilodalton tegument protein of the virus particle, pp65 (ppUL83)(PK)), ${ }^{13}$ were used.

Table 1 Results of dot blot hybridisation, in situ hybridisation and PCR

\begin{tabular}{|c|c|c|c|c|c|c|c|c|c|c|c|c|c|c|c|}
\hline \multirow[b]{2}{*}{ Test } & \multirow[b]{2}{*}{ Tissue } & \multicolumn{13}{|c|}{ Subject number } & \multirow[b]{2}{*}{ Total } \\
\hline & & 1 & 2 & 3 & 4 & 5 & 6 & 7 & 8 & 9 & 10 & 11 & 12 & 13 & \\
\hline \multirow{3}{*}{ Dot blot hybridisation } & Aorta & + & + & NA & + & NA & NA & - & + & + & NA & NA & + & NA & $6 / 7$ \\
\hline & Spleen & + & + & + & + & + & NA & + & + & + & NA & NA & + & + & $10 / 10$ \\
\hline & Pancreas & NA & + & - & - & + & NA & - & NA & NA & NA & NA & NA & + & $3 / 6$ \\
\hline \multirow[t]{3}{*}{ In situ hybridisation } & Aorta & + & + & + & + & + & - & - & + & - & - & - & + & NA & $6 / 12$ \\
\hline & Spleen & + & + & + & + & + & NA & + & - & + & - & - & + & + & $8 / 12$ \\
\hline & Pancreas & NA & + & + & + & + & NA & - & NA & + & NA & + & NA & + & $6 / 7$ \\
\hline \multirow[t]{3}{*}{ Nested PCR } & Aorta & + & + & + & + & + & - & - & + & + & - & + & + & NA & $9 / 12$ \\
\hline & Spleen & + & + & + & + & + & NA & + & + & + & + & + & + & + & $12 / 12$ \\
\hline & Pancreas & NA & + & + & + & + & NA & - & NA & + & + & + & NA & + & $6 / 8$ \\
\hline Serology & & - & + & - & + & + & - & + & - & + & + & + & + & + & $4 / 13$ \\
\hline
\end{tabular}

NA $=$ not available. 

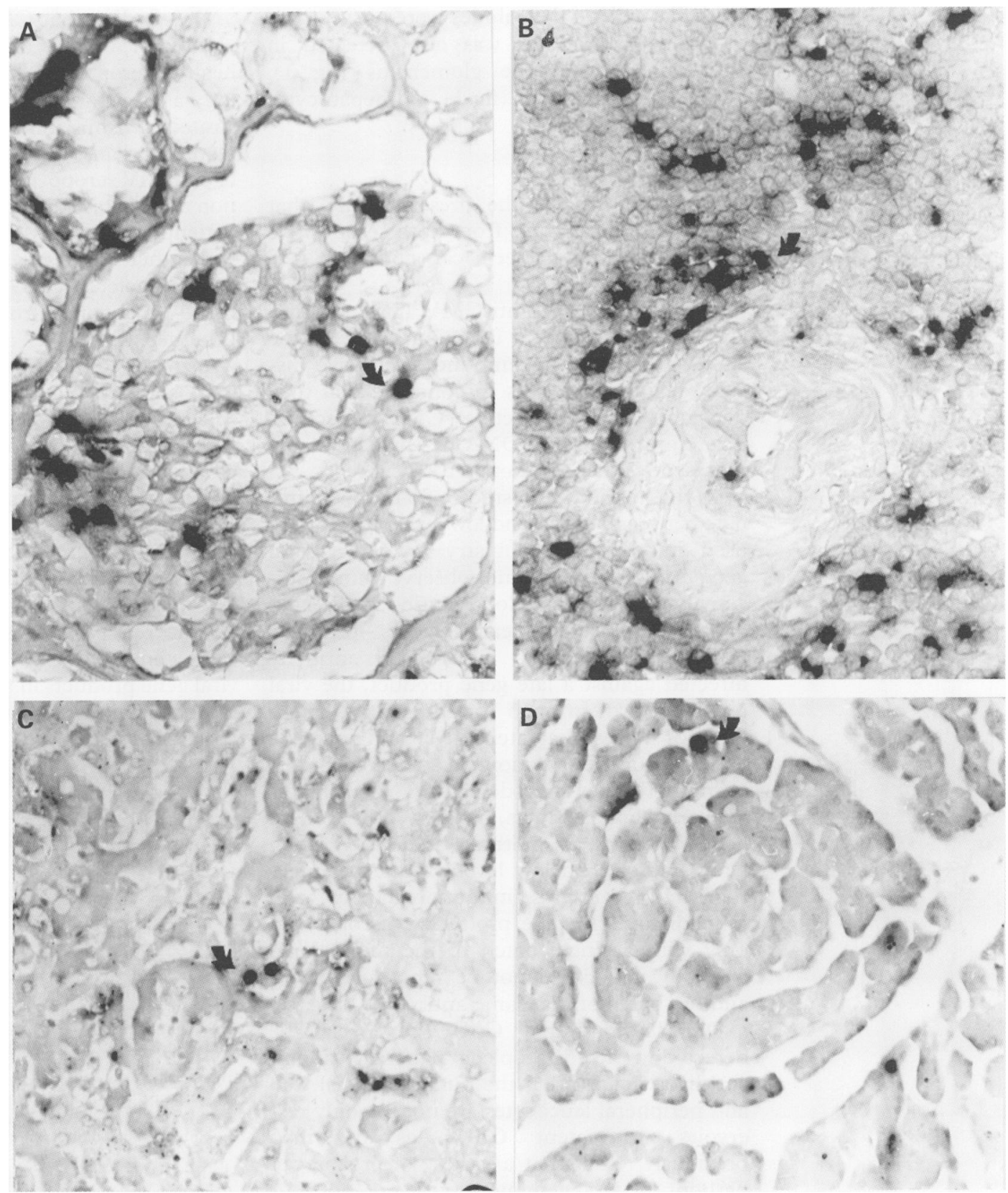

Figure 1 In situ DNA hybridisation (arrow) of samples from four organs, using CMV specific probes. All sections were counterstained with methyl green. (A) Kidney, (B) spleen, (C) liver, and (D) pancreas. (Original magnification $\times 400$.)

\section{Results}

SEROLOGY

Serum samples from four group 1 subjects did not contain CMV antibodies. All other subjects were CMV positive. Results of all IgG tests showed $100 \%$ agreement. No CMV reactive antibodies of the IgM class were detected, indicating that none of the subjects had had active CMV disease.

\section{IMMUNOHISTOCHMISTRY}

Immunohistochemical studies were done using both monoclonal antibodies. Immunoreactivity was not observed in any of the samples tested.

\section{DOT BLOT HYBRIDISATION}

Twenty three tissue samples from group 1 subjects were subjected to dot blot hybridisation. Overall, six of seven samples of aorta, 10 of 10 samples of spleen and three of six samples of pancreas harboured CMV DNA (table 1). Tissue samples from three of four seronegative donors (two aorta, three spleen and one pancreas) were evaluated using this technique. Of these, samples of aorta and spleen contained viral DNA, while that of the pancreas did not.

\section{PCR}

In group 1 (table 1), nine of 13 abdominal aorta, 12 of 12 spleen, and six of eight pancreatic samples contained viral DNA. CMV DNA was also found in three of four seronegative subjects. In group 2, eight of eight spleen, eight of eight liver and eight of eight kidney samples harboured CMV DNA. The few samples which did not react with the CMV primers reacted well with the $\beta$-globin primers.

None of the numerous negative controls included nor any of the samples containing DNA from the other known herpesviruses were positive.

IN SITU HYBRIDISATION

The red pulp of the spleen often contained CMV positive cells (fig 1 ). In the kidney the 
epithelial cells of the tubules were positive frequently. CMV DNA was also detected in epithelial cells of the glomerulus (fig 1). Pancreatic acinar cells (fig 1) and hepatocytes were often positive.

\section{Discussion}

We have shown, in the present study, that potential donor organs from both seropositive and seronegative subjects can contain CMV DNA.

All subjects were anti-CMV IgM negative, excluding active CMV infection. None of the subjects had had an immunosuppressive disease, again allowing us to conclude that they did not have an active CMV infection. Therefore, the CMV DNA detected probably represents latent and not active virus.

As the hybridisation studies do not discriminate between latency and low level infection we used immunohistochemistry to detect viral gene products. We did not observe immunoreactivity with a monoclonal antibody directed against immediate early gene products (UL123) nor with a monoclonal antibody directed against a late gene product, the viral tegument protein pp65 (ppUL83(pk)). These findings suggest that latent CMV and not a low level productive infection was detected. Interestingly, Toorkey $e t a l^{14}$ detected CMV immediate early gene products, but not early nor late gene products, in normal tissue suggesting latent rather than low level productive infection. However, this immunoreactivity with immediate early gene products was observed only with a single batch of the monoclonal antibody and could not be reproduced with another batch of that same antibody.

Our findings that CMV DNA can be detected in the aorta, spleen, pancreas, kidney, and liver suggest that the human arterial wall and peripheral leucocytes are not the only reservoirs for latent CMV, as described previously, ${ }^{3-8}$ but that a variety of organs can harbour the viral genome.

PCR is very sensitive to cross contamination between specimens ${ }^{15}$ and to contamination by previously amplified DNA. ${ }^{12}$ However, the overall agreement of results obtained by dot blot hybridisation, in situ hybridisation and PCR, and the absence of viral DNA in the numerous negative controls included in the PCR experiments in this study preclude the possibility of cross contamination.

PCR studies of murine cytomegalovirus (MCMV) have shown that lung, spleen, brain, heart, kidney, liver, and salivary glands harbour latent MCMV DNA. ${ }^{16-19}$ The exact nature of the cell(s) carrying this MCMV DNA remain obscure. As shown in the present study by in situ DNA hybridisation, many different cell types, such as hepatocytes, tubular and glomerular cells, and splenic red pulp cells, contained viral DNA. During active infection the virus is distributed widely and replicates in virtually all cell types as shown by the appearence of specific viral cytopathological changes, the presence of viral antigens and the presence of viral DNA in various cells in almost all organs. ${ }^{2021}$
Our finding that CMV DNA is present in a variety of organs obtained from previously healthy seropositive subjects was not surprising, as several studies have clearly demonstrated transmission of CMV present in transplanted organs and peripheral blood obtained from CMV seropositive donors. ${ }^{22}$ The observation that in this study three of four seronegative patients carried CMV DNA is in accordance with other reports describing the presence of CMV nucleic acids in leucocytes ${ }^{7823}$ and tissue $^{2526}$ obtained from seronegative patients. Whether this CMV DNA represents latent virus or defective virus remains unknown.

In summary, a variety of organs such as spleen, kidney, liver, and pancreas contain CMV DNA as demonstrated by PCR and dot blot hybridisation. The presence of CMV DNA was demonstrated in seropositive and also in a number of seronegative subjects by dot blot hybridisation, in situ hybridisation and nested PCR. Arterial smooth muscle cells, hepatocytes, tubular and glomerular kidney cells, splenic red pulp cells and pancreatic acinar cells, contained CMV DNA. The absence of viral gene products in these cells suggests latent rather than low level active infection.

1 Ho M. Cytomegalovirus biology and infection. New York: Plenum Press, 1982.

2 Chou S. Acquisition of donor strains of cytomegalovirus by renal transplant recipients. $N$ Engl f Med 1986;314:141822.

3 Melnick JL, Petrie BL, Dreesman GR, Burek J, McCollum $\mathrm{CH}$, Debakey ME. Cytomegalovirus antigen within human arterial smooth muscle cells. Lancet 1983,ii:644-7.

4 Yamashiroya HM, Ghosh L, Yang R, Robertson L. Herpes viridae in the coronary arteries and aorta of young trauma victims. Am $\mathcal{F}$ Pathol 1988;130:71-9.

5 Hendrix MGR, Salimans MMM, van Boven CPA, Bruggeman CA. High prevalence of latently present cytomegalovirus in arterial walls of patients suffering from grade III atheroclerosis. Am F Pathol 1990;136:23-8.

6 Hendrix MGR, Daemen M, Bruggeman CA. Cytomegalovirus nucleic acid distribution within the human vascular tree. Am ₹ Pathol 1991;138:563-7.

7 Bevan IS, Daw RA, Day PJR, Ala FA, Walker MR. Polymerase chain reaction for detection of human cytomegalovirus ase chain reaction for detection of human cytomegalovirus
infection in a blood donor population. Br f Haematol 1991; 78:94-9.

8 Taylor-Wiedeman J, Hayhurst GP, Sissons JGP, Sinclair JH. Polymorphonuclear cells are not sites of persistence of human cytomegalovirus in healthy individuals. $\mathcal{f}$ Gen Virol 1993;74:265-8.

9 Kraat YJ, Hendrix MGR, Landini MP, Bruggeman CA. Comparison of four techniques for detection of antibodies to CMV. $¥$ Clin Microbiol 1992;30:522-4.

10 van Loon AM, Heessen FWA, van der Logt JThM, van der Veen J. Direct enzyme linked immunosorbent assay that uses peroxidase-labelled antigen for determination of IgM antibody to cytomegalovirus. $\mathcal{F}$ Clin Microbiol 1981;13:41622 .

1 Saiki RK, Schauf S, Faloona F, Mullis KB, Horn GT, Ehrlich A, Arnheim N. Enzymatic amplification of $\beta$-globin genomic sequences and restriction site analysis for diagnosis of sickle cell aremia. Science 1985;230:1350-4.

12 Hendrix MGR, Dormans PHJ, Kitslaar P, Bosman F, Bruggeman CA. The presence of CMV nucleic acids in arterial walls of atherosclerotic and non-atherosclerotic patients. Am f Pathol 1989;134:1151-7.

13 Lijnschoten G, Stals F, Bruggeman CA, Havenith $\mathrm{MH}$, Geraedts JPM. The presence of cytomegalovirus antigens in karyotyped abortions. Am $\mathscr{f}$ Reprod Immunol 1994;32: in karyotyp

14 Toorkey CB, Carrigan DR. Immunohistochemical detection of an immediate early antigen of human cytomegalovirus in normal tissues. $\mathcal{F}$ Infect Dis 1989;160:741-51.

15 Persing DH. Polymerase chain reaction: trenches to benches. F Clin Microbiol 1990;29:1281-5.

16 Klotman ME, Henry SC, Greene RC, Brazy PC, Klotman ME, Hamilton JD. Detection of mouse cytomegalovirus nucleic acid in latently infected mice by in vitro enzymatic amplification. F Infect Dis 1990;161:220-5.

17 Balthesen $M$, Messerle $M$, Reddehase MJ. Lungs are a major organ site of cytomegalovirus latency and recurmajor organ site of cytomegalov

18 Collins T, Pomeroy C, Jordan MC. Detection of laten cytomegalovirus DNA in diverse organs of mice. $\mathcal{F}$ Infect Dis 1993;168:725-9. 
19 Yuhasz SA, Dissette VB, Cook ML, Stevens JG. Murine cytomegalovirus is present in both chronic active and latent states in persistently infected mice. Virology 1994;202:27280.

20 Myerson P, Hackman RC, Nelson JA, Ward DC, McDougal JK. Widespread presence of histologically occult cytomegalovirus. Hum Pathol 1984;15:430-9.

21 Wu T-C, Lee WA, Pizzorno MC, Au W-C, Chan Y-J, Hruban $\mathrm{RH}$, et al. Localization of the human CMV $2.7-\mathrm{kb}$ major early B-gene transcript by RNA in situ hybridization in permissive and nonpermissive infections. Am $\mathcal{F}$ Pathol 1992;141:1247-54.

22 Ho M. Epidemiology of cytomegalovirus infections. Rev Infect Dis 1990;12:S701-10.

23 Stanier $P$, Taylor DL, Kitchen AD, Wales N, Tryhorn Y, Tyms AT. Persistence of cytomegalovirus in mononuclear cells in peripheral blood from blood donors. $B M \mathcal{F}$ 1989;299:897-8.

24 Zang LJ, Hanff P, Rutherford C, Churchill WH, Crumpacker CS. Detection of HCMV DNA-RNA and antibody in normal blood donors. F Infect Dis 1995;171: 1002-6.

25 Kraat YJ, Hendrix MGR, Wijnen RMH, Peltenburg HG, van Hooff JP, Geelen JLMC, et al. Detection of latent human cytomegalovirus in organ tissue and the correlation with serological status. Transplant Int 1992;5(Suppl 1):S613-16.

26 Schonlan U, Crombach M, Maisch B. Assessment of cyomegalovirus DNA and protein expression in patients with myocarditis. Clin Immunol Immunopathol 1993;68: 229-33. 